\title{
Insulin Secretion by the Transplanted Neonatal Pancreas during Food Intake in Fasted and Fed Rats
}

\author{
J. H. Strubbe and P. van Wachem \\ Department of Zoology, State University of Groningen, Haren, The Netherlands
}

Summary. In order to investigate the physiological role of the autonomic nervous system on insulin secretion, neonatal pancreases were implanted under the kidney capsule of alloxan diabetic rats, resulting in recovery from diabetes, with denervated insulin secreting tissue. Rats were also provided with permanent double cardiac catheters allowing simultaneous infusion and rapid blood sampling with free movement. Intracardiac glucose infusion caused, coincident with the rapid rise of blood glucose, an increase of plasma insulin in the first minute in both controls and transplanted rats. After ingestion of food plasma insulin in normal control rats increased in the first minute, and prior to the first rise of glucose, from 23 $\pm 2 \mathrm{mU} / 1$ to $66 \pm 4 \mathrm{mU} / 1$ in the fed state, and from 9 $\pm 3 \mathrm{mU} / 1$ to $34 \pm 3 \mathrm{mU} / 1$ after $24 \mathrm{~h}$ of fasting. In contrast, this response was absent in the transplanted animals. In the fed state maximum insulin responses were attained at 20 minutes and were $63 \pm 10 \mathrm{mU} / 1$ for controls, $104 \pm 15 \mathrm{mU} / \mathrm{l}$ for transplants and $20 \pm$ $3 \mathrm{mU} / \mathrm{l}$ for rats which recovered from diabetes one week after alloxan. The concomittant glucose responses were $22 \pm 2,34 \pm 3$ and $45 \pm 4 \mathrm{mg}$ / $100 \mathrm{ml}$ respecitively. Ingestion of a meal after fasting showed a similar decreased insulin response and insulinogenic index at $\mathrm{t}=20$ in both the transplanted and control group. Histology and electronmicroscopy of the transplanted pancreas showed vascularized groups of well granulated B-cells. The data of these experiments suggest that 1) The early insulin response after food intake is under direct control of the autonomic nervous system, 2) Glucose homeostasis is disturbed after transplantation, 3) Mainly humoral factors are responsible for the decreased insulin response after fasting.

Key words: Insulin secretion, glucose homeostasis, food intake, fasting, pancreas transplantation, neonatal rat pancreas, B-cell innervation
Food intake is generally considered to be the main physiological stimulus for insulin release. In rats ingesting a carbohydrate rich meal plasma insulin increases in the first minute whereas blood glucose increases in the third minute [1-3]. Both atropine administration and vagotomy abolish this early insulin response (EIR) [1, 4, 5-7]. These results suggest that the vagus nerve may be involved in this early response and that the response is mediated by cholinergic action on muscarinic receptors. However, it is not clear whether this is a direct effect of the vagus on the endocrine pancreas, or a vagally mediated release of enteric hormones [8].

In vitro and in vivo studies have shown that fasting reduces the glucose-induced insulin secretion of the rat [9-11]. This phenomenon, which is already evident after $24 \mathrm{~h}$ of fasting, has been attributed to decreased c-AMP formation in B-cells involved in the insulin release [12-14]. So far very little is known about possible factors external to B-cells. A decreased blood glucose level may be one of the causal factors $[12,15]$. Other possible factors are decreased plasma levels of insulinotropic enteric hormones, increased sympathetic tone, or decreased activity of the vagus nerve $[16,17]$. Evidence for the latter was obtained from a decreased EIR after fasting [1,2].

The aim of this study was to investigate the role of the autonomic nervous system in the origin of the EIR and in the decreased insulin release after fasting. For this purpose pancreatic islet cell transplantation was used to obtain denervated insulin producing tissue which could only be stimulated by humoral factors.

\section{Materials and Methods}

\section{Animals}

Male rats of the highly inbred $\mathrm{AO}$ strain weighing 305-330 g were kept in plexiglass cages at a room temperature of $\pm 20^{\circ} \mathrm{C}$. Daily collection of urine was possible by means of a urine-faeces 
separator placed below the cage floor. The cages were lit from $0600 \mathrm{~h}$ to $1800 \mathrm{~h}$. Food and water were freely supplied unless otherwise stated. The diet consisted of $20 \%$ protein, $53.5 \%$ carbohydrate, $4.5 \%$ fat and $22 \%$ water.

Experimental diabetes was produced by an intravenous injection of alloxan $45 \mathrm{mg} / \mathrm{kg}$ body weight (BDH Chemicals, Poole, England) after $24 \mathrm{~h}$ fasting. In some of the rats treated with alloxan, glycosuria disappeared 7-9 days after alloxan injection. These rats probably regenerated their insulin producing tissue. This regenerated group was used for comparison with the other groups.

\section{Renal Subcapsular Transplantation}

After three to four weeks the diabetic rats received 8 pancreases each, placed under the kidney capsules as described by Brown [18]. The pancreases were obtained from first-day neonates. Diabetic, regenerated and non-diabetic $(n=6)$ control rats were sham operated. All rats were given $6 \mathrm{U}$ protamine zinc insulin (Organon, The Netherlands) SC for three days.

\section{Implantation of Cannulae}

Two weeks after transplantation, the rats were provided with a double permanent cardiac catheter [19] with a small swivel joint in the connecting tubes [20]. These catheters allow blood sampling and intracardiac infusion. The infusion catheter was $3 \mathrm{~mm}$ longer than the sample catheter in order to prevent contamination of the blood samples with the infused fluid. The rats were handled for about a week to accustom them to the sampling procedure. Blood samples of $0.2 \mathrm{ml}$ were taken and heparinised. Blood was replenished by transfusion of citrated blood through the sample catheter during the experiments.

\section{Experimental Design and Conditions}

Five to six weeks after transplantation the response of the transplanted B-cells to glucose stimulation was tested by infusing glucose $(10 \mathrm{~g} / 100 \mathrm{ml})$ dissolved in distilled water over a period of $15 \mathrm{~min}$ at a rate of $0.1 \mathrm{ml} / \mathrm{min}(10 \mathrm{mg} / \mathrm{min})$. Five days later the animals response to spontancous ingestion of a meal was tested using $2 \mathrm{~g}$ of their diet mixed with $2 \mathrm{~g}$ water. Each animal was tested twice, in the fed state (food withdrawn $2 \mathrm{~h}$ before the test) and after $24 \mathrm{~h}$ fasting. These tests were conducted in random order and were separated by at least 5 days. For comparison the regenerated rats and the sham operated diabetic rats were tested in a similar way.

Blood samples $(0.2 \mathrm{ml})$ were taken $10 \mathrm{~min}(\mathrm{t}=-10)$ and immediately before the oral or IV test $(t=0)$. The response was studied by sampling at $1,2,3,5,10$, and $15 \mathrm{~min}$ after beginning the test. Additional samples were taken in the oral test at 20,25 , $30,40,50$, and $60 \mathrm{~min}$. Tests were always performed between $0900 \mathrm{~h}$ and $1200 \mathrm{~h}$.

\section{Insulin and Glucose Determinations}

The presence of glucose in the urine was detected by Lilly TesTape (Bipharma N. V., Amsterdam).

Blood samples were immediately chilled and centrifuged at $4{ }^{\circ} \mathrm{C}$. The plasma was stored at $-20^{\circ} \mathrm{C}$ until analysis. The blood glucose concentration was measured by a ferricyanide method with a Technicon Autoanalyzer. Insulin was measured by a radioimmunoassay kit (Novo, Denmark) using a rat insulin standard, ${ }^{125} \mathrm{I}$ labelled pork insulin and antipork insulin guinea pig serum M8309. Duplicate assays were performed on $25 \mu \mathrm{l}$ samples. $25 \mu \mathrm{I}$ of plasma from alloxan-diabetic rats was added to each of the standards. The separation of bound and free ${ }^{125} \mathrm{I}$-labelled insulin was performed by means of polyethylene glycol $(23.75 \% \mathrm{w} / \mathrm{v})$ in water. The coefficient of variation of the immunoassay was $<8 \%$.

\section{Histological Procedures}

In order to investigate vascularisation and granulation of the transplants, the tissue was subjected to light-and electron-microscopy.

Two months after transplantation the transplanted pancreatic tissue and the pancreases were removed, fixed in Bouin's solution, embedded in paraffin and stained with aldehyde fuchsin. For a more precise examination of granulation in the middle and at the periphery of the cells, electronmicroscopy was performed on transplanted tissue. The tissue was fixed in $3 \%$ glutaraldehyde $(\mathrm{v} / \mathrm{v})$ for one hour in $0.1 \mathrm{~mol} / \mathrm{l} \mathrm{Na}$-cacodylate buffer $\mathrm{pH} \mathrm{7.2,} \mathrm{washed} \mathrm{for}$ $30 \mathrm{~min}$ with buffer, and postfixed in a mixture of $1 \%$ osmium tetroxide $(\mathrm{w} / \mathrm{v})$ and $21 / 2 \%$ potassium dichromate $(\mathrm{w} / \mathrm{v})$ in $0.1 \mathrm{~mol} / 1$ Na-cacodylate pH 7.2 for $45 \mathrm{~min}$. After poststaining in $1 \%$ uranylacetate $(\mathrm{w} / \mathrm{v})$ for $60 \mathrm{~min}$ the tissue was dehydrated in a graded alcohol series, and embedded in epon. Ultrathin sections were cut on an LKB ultratome with a diamond knife and examined in a Philips EM 300 without further staining.

\section{Statistical Analysis and Calculations}

Differences were tested for statistical significance with Student's t-test (two-tailed), $\mathrm{p}<0.05$ being considered significant. Some of the results are expressed as the insulinogenic index (change in insulin/change in glucose). Results are stated as mean \pm SEM.

\section{Results}

\section{Effect of Pancreatic Transplantation on Body Weight and Urine Production}

After IV alloxan injection the rats developed glycosuria $(>2 \mathrm{~g} / 100 \mathrm{ml})$ and polyuria $(>100 \mathrm{ml} /$ $24 \mathrm{~h}$ ). Figure 1 demonsirates the effect of pancreatic transplantation on body weight and urine production. At the time of transplantation (T) insulin injection (I) caused a drop in urine production. Thereafter urine volume increased and glucose reappeared in the urine. A gradual increase in body weight appeared from day 11 after transplantation. On this day urine volume was almost normal and there was no glycosuria. In the sham operated diabetic controls insulin injections caused a transistory increase in body weight and temporary decrease in glycosuria.

\section{Intravenous Glucose Infusion}

The mean pre-infusion blood glucose level in transplanted rats was not different from those of control rats (Fig. 2). In control rats blood glucose concentration increased immediately after starting the glucose infusion, the most rapid rise occurring during the initial 5 min followed by a less rapid increase until the 


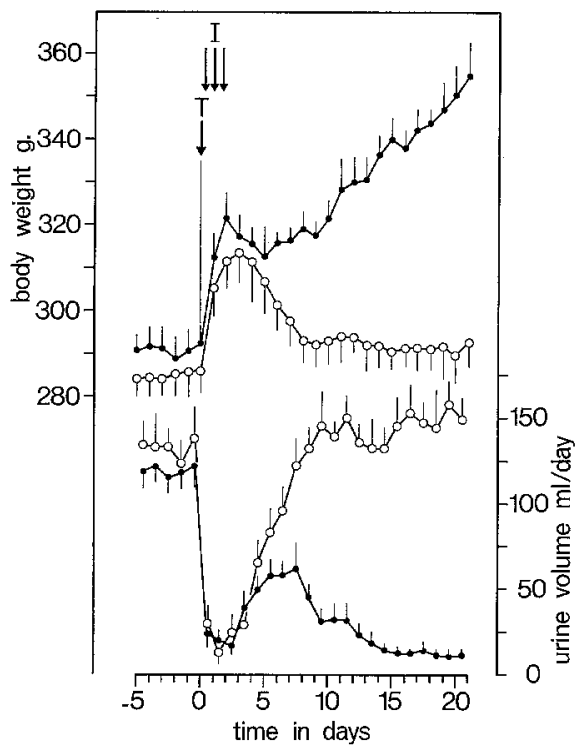

Fig. 1. Body weight and urine production of a transplanted group - $(n=6)$ and a non-transplanted diabetic sham group $O \_(n=6)$. Mean \pm SEM. Transplantation $(T)$ and insulin injections (I) indicated by arrows

end of the infusions at $15 \mathrm{~min}$. In the transplanted rats the same pattern was seen. The basal insulin level of both groups of rats was similar. In both groups there was a rapid rise of blood glucose and a marked increase of plasma insulin within the first minute. The one min insulin value marked the first phase of a typical biphasic response pattern. A second rise of plasma insulin occurred from $5 \mathrm{~min}$ onward and lasted at least until the end of the infusion period at $15 \mathrm{~min}$. Although the insulin level of the transplanted rats tended to be lower, there were no significant differences between these and the control rats.

\section{Food Intake}

The starting glucose and insulin levels $(t=0)$ between the transplanted group and the controls were not significantly different. In both groups fasting decreased the basal insulin and glucose level ( $\mathrm{p}<$ 0.01 ). In both conditions and in both groups the first noticeable rise of blood glucose occurred $2 \mathrm{~min}$ after the start of a meal (Fig. 3). Maximum levels were attained in the fed state between 10 and $25 \mathrm{~min}$ and in the fasted condition between 15-30 min. In the fed state the blood glucose level of the transplanted group increased much more during the first $10 \mathrm{~min}$ than that of the controls $(33 \pm 4$ and $16 \pm 1 \mathrm{mg}$ / $100 \mathrm{ml}(\mathrm{p}<0.02)$ respectively).

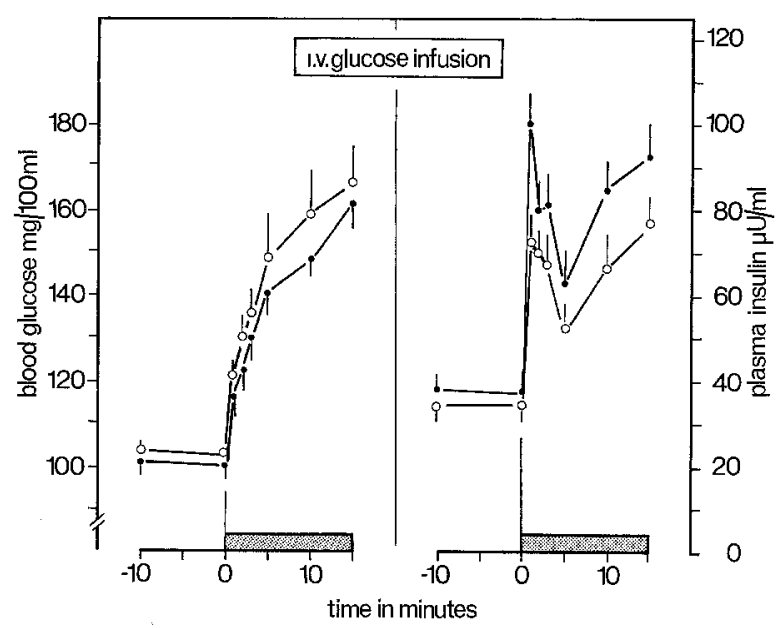

Fig. 2. Comparison of plasma insulin and blood glucose (mean \pm SEM) between control $\longrightarrow(\mathrm{n}=6)$ and transplanted rats $O-O(n=6)$. Intravenous infusion of glucose was given over $15 \mathrm{~min}$. The response was tested five weeks after transplantation

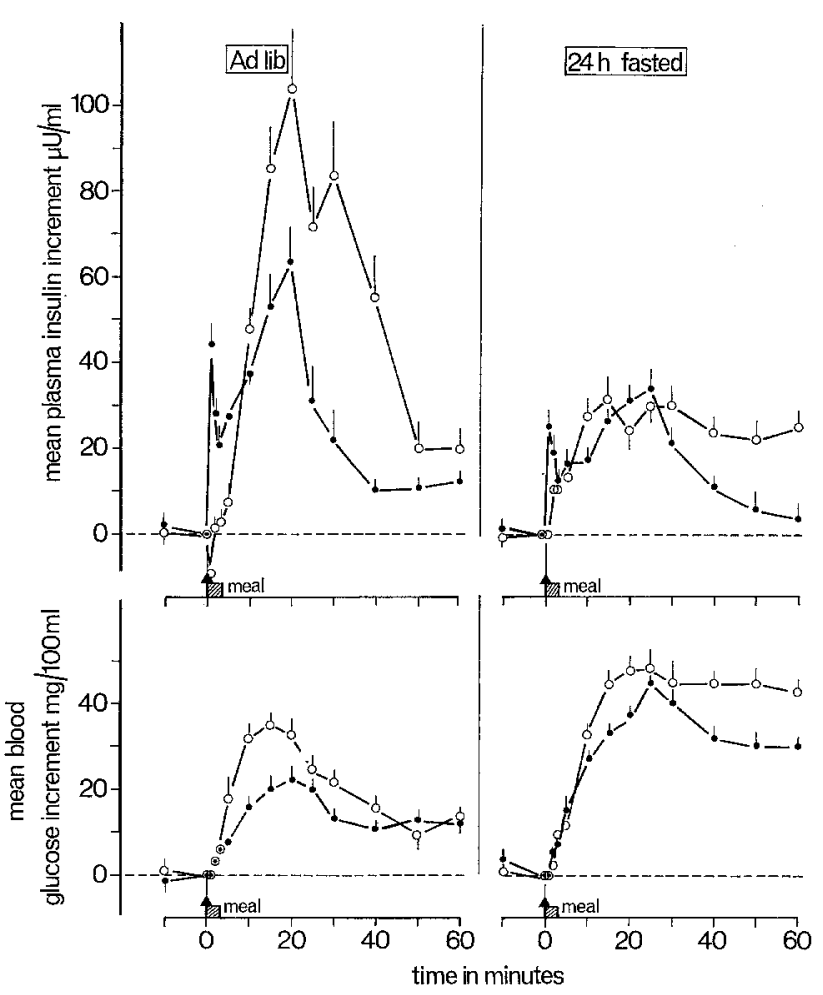

Fig. 3. Comparison of plasma insulin and blood glucose responses (mean \pm SEM) between control $\longrightarrow(n=6)$ and transplanted rats $\mathrm{O}-\mathrm{O}(\mathrm{n}=6)$. The figure shows the effect of food intake $(4 \mathrm{~g})$ in the fed state and after fasting. The response was tested six weeks after transplantation. Absolute basal plasma insulin levels were in the controls: fed $23 \pm 2 \mathrm{mU} / \mathrm{l}$ and $24 \mathrm{~h}$ fasted $9 \pm 3 \mathrm{mU} / \mathrm{l}$; and in the transplanted group: fed $26 \pm 3 \mathrm{mU} / 1$ and $24 \mathrm{~h}$ fasted 10 $\pm 2 \mathrm{mU} / \mathrm{l}$. Absolute basal blood glucose levels were in the controls: fed $105 \pm 1 \mathrm{mg} / 100 \mathrm{ml}$ and $24 \mathrm{~h}$ fasted $86 \pm 2 \mathrm{mg} / 100 \mathrm{ml}$; and in the transplanted group: fed $102 \pm 1 \mathrm{mg} / 100 \mathrm{ml}$ and fasted $88 \pm 2 \mathrm{mg} / 100 \mathrm{ml}$ 


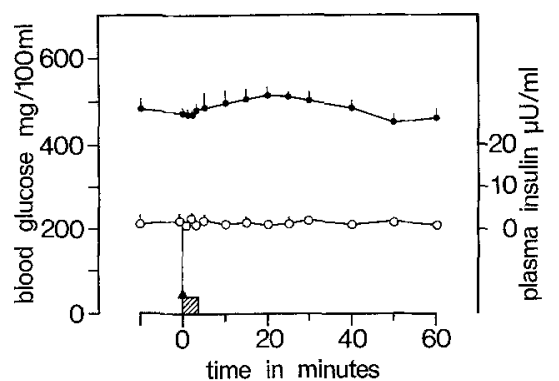

Fig. 4. Effect of food intake (4 g) on blood glucose $\longrightarrow$ and plasma insulin $\mathrm{O}-\mathrm{O}$ of the non-transplanted diabetic shamoperated group (mean \pm SEM)

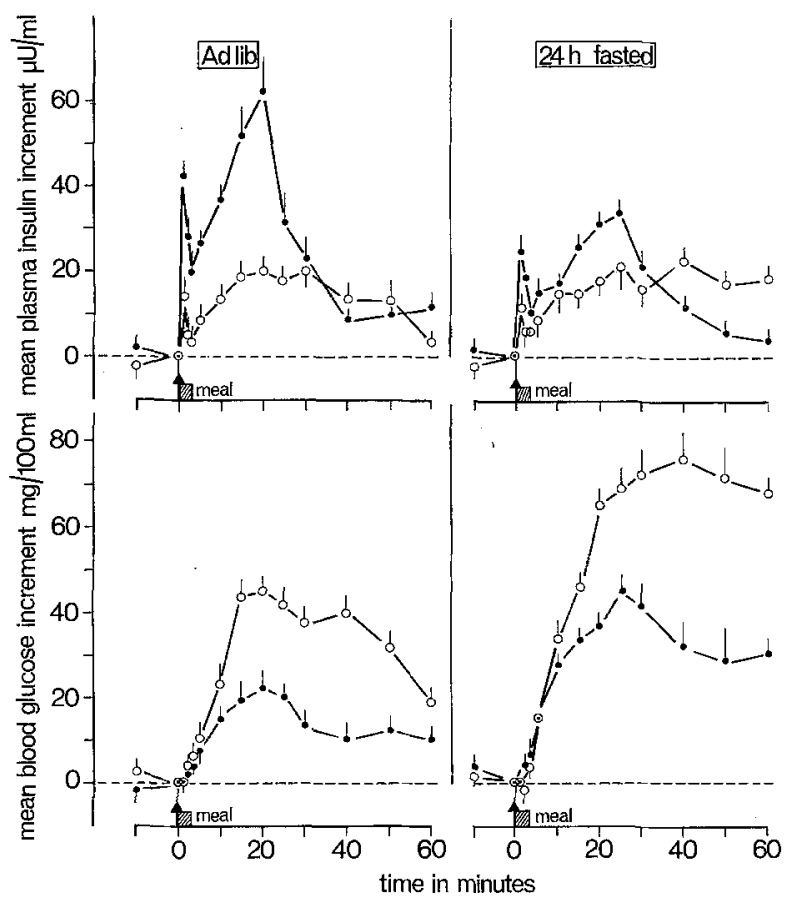

Fig. 5. Comparison of plasma insulin and blood glucose responses (mean \pm SEM) between control $-(n=6)$ and regenerated rats $\mathrm{O}-\mathrm{O}(\mathrm{n}=6)$. The figure shows the effect of food intake $(4 \mathrm{~g})$ in the fed state and after fasting. The response was tested six weeks after sham-transplantation. Absolute basal plasma insulin levels were in the controls: fed $23 \pm 2 \mathrm{mU} / 1$ and $24 \mathrm{~h}$ fasted $9 \pm 3$ $\mathrm{mU} / 1$, and in the regenerated group: fed $22 \pm 3 \mathrm{mU} / 1$ and $24 \mathrm{~h}$ fasted $10 \pm 1 \mathrm{mU} / \mathrm{l}$. Absolute basal blood glucose levels were in the controls: fed $105 \pm 1 \mathrm{mg} / 100 \mathrm{ml}$ and $24 \mathrm{~h}$ fasted $86 \pm 2 \mathrm{mg} /$ $100 \mathrm{ml}$ and in the regenerated group: fed $109 \pm 1 \mathrm{mg} / 100 \mathrm{ml}$ and fasted $87 \pm 2 \mathrm{mg} / 100 \mathrm{ml}$

In the fed control rats plasma insulin increased by about $200 \% 1 \mathrm{~min}$ after the start of meal ingestion, that is $1 \mathrm{~min}$ before the first noticeable rise of blood glucose (Fig. 3). In contrast, this pre-absorptive insulin response was absent in the transplanted group. Plasma insulin in these recipients in the fed state reached higher levels than those of controls, achieving peak levels at $20 \mathrm{~min}$ (transplanted $104 \pm 15$ and controls $63 \pm 9 \mathrm{mU} / \mathrm{l}, \mathrm{p}<0.05$ ). These peak levels appear to coincide with the maximum blood glucose levels. Thereafter plasma insulin decreased to levels slightly above the starting values. However, in the transplanted group the decline of the plasma insulin level was slower.

In fasted control rats a biphasic secretion pattern was seen but lower peak levels were reached. In fasted recipients, the secretory response reached the same peak level as in the fasted control rats but the EIR was absent. Both groups also showed similar peak levels for glucose. The insulin levels of control rats decreased between 25 and $60 \mathrm{~min}$ to about base line levels, in spite of relatively high glucose levels. In contrast, insulin of recipients remained at high levels.

Comparing the quantitative differences between fed and fasting it is clearly demonstrated that in controls the pre-absorptive insulin response was lower in the fasted than in the fed condition ( $26 \pm 2$ versus 43 $\pm 3 \mathrm{mU} / \mathrm{l}, \mathrm{p}<0.02$ ). The maximum increase of the second phase in the fasted state was lower than in the fed state for both the control group $(34 \pm 5$ versus 63 $\pm 9 \mathrm{mU} / \mathrm{l}, \mathrm{p}<0.05)$ and for the transplanted group $(32 \pm 6$ versus $104 \pm 15 \mathrm{mU} / 1, \mathrm{p}<0.01)$ respectively. The opposite was true for the glucose levels in the controls ( $46 \pm 2$ versus $22 \pm 2 \mathrm{mg} / 100 \mathrm{ml}, \mathrm{p}<$ $0.01)$ and transplanted rats $(48 \pm 5$ versus $35 \pm$ $2 \mathrm{mg} / 100 \mathrm{ml}, \mathrm{p}<0.05$ ).

The blood glucose and plasma insulin levels of sham-operated diabetic rats $(n=6)$ varied after meal ingestion from 480 to $550 \mathrm{mg} / 100 \mathrm{ml}$ and 0 to $3 \mathrm{mU} / 1$ respectively (Fig. 4 ).

The effect of food intake in the regenerated group is shown in Fig. 5. The starting glucose and insulin levels of the regenerated group and the controls were not significantly different. After fasting blood glucose and plasma insulin were lower and were not different between both groups. Blood glucose levels of the regenerated group increased more than those of the control group in particular from 10 min onwards. This contrasts with effects observed in the preceding experiments in which blood glucose increased more during the first $10 \mathrm{~min}$ in the transplanted group. Although an EIR was present in the regenerated group in both conditions, this response was lower than in the controls. The overall response of first (EIR) and second phase were lower in both conditions than those of the controls $(p<0.05)$. In the regenerated group almost no differences were observed between the insulin responses in the fed and fasted condition. The insulinogenic index at $\mathrm{t}=20$ for the regenerated rats in fed and fasted state was $0.48 \pm 0.09$ and $0.28 \pm 0.03(p<0.01)$, whereas 

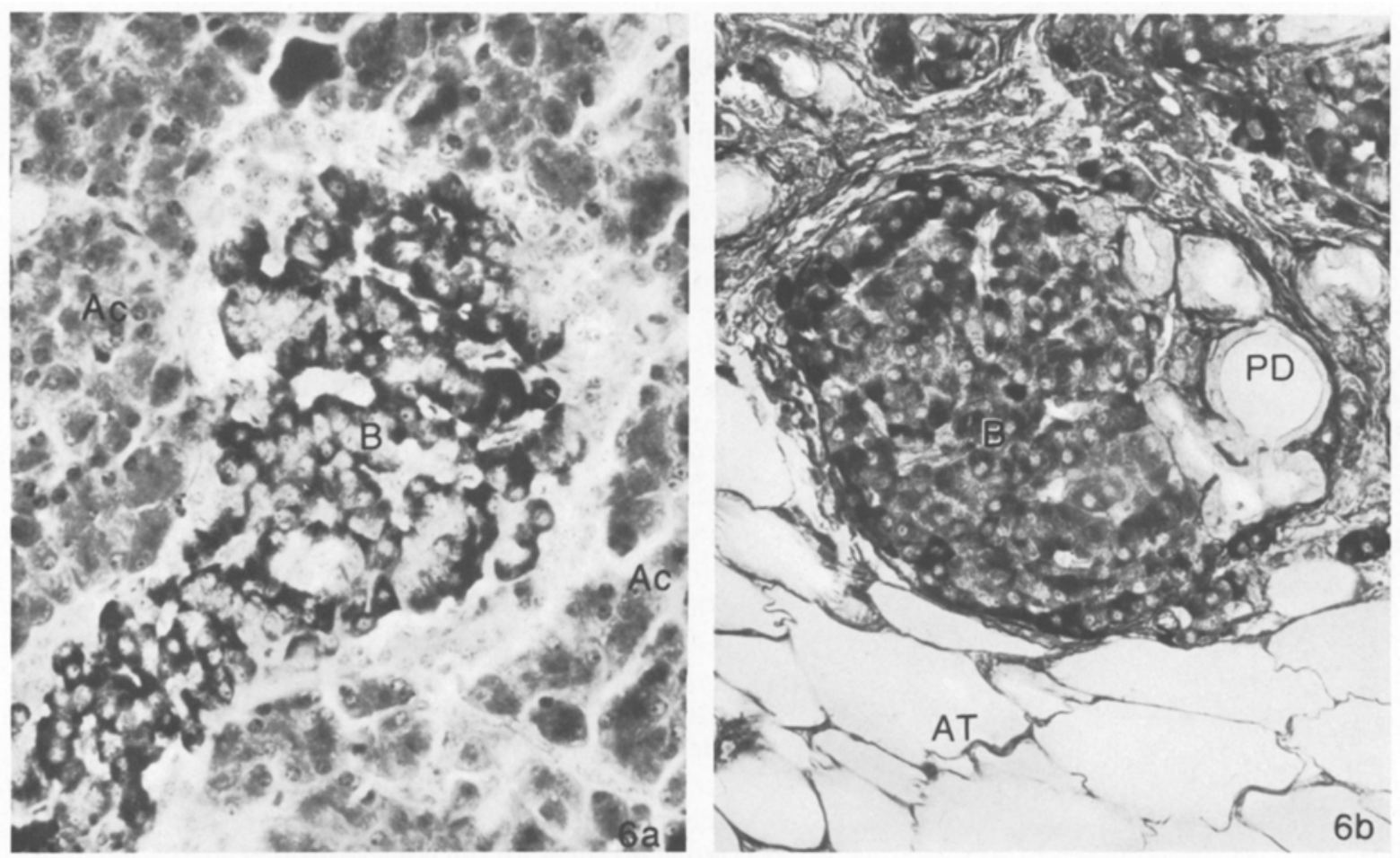

Fig. 6. a Islet of Langerhans from a control rat. Aldehyde fuchsin positive, B-cells predominate (B). The light border of the islets contains other endocrine A and D cells. Acinar tissue surrounds the islet (Ac) Aldehyde Fuchsin, $\times 580$. $b$ Appearance of a part of the pancreas transplant removed 55 days after transplantation. Adipose tissue (AT) surrounds the transplants. Clusters of B-cells (B) and pancreatic ducts (PD). Note the absence of a light border of other endocrine cells. Aldehyde Fuchsin $\times 580$

these values were for the control rats $2.94 \pm 0.40$ and $0.84 \pm 0.03(\mathrm{p}<0.01)$ and for the transplanted rats $3.44 \pm 0.80$ and $0.53 \pm 0.10(\mathrm{p}<0.01)$ respectively.

\section{Histology and Electronmicroscopy}

There were $1-2 \%$ of stained B-cells left in the original pancreases of the transplanted group. Histology of the transplanted tissue showed clusters of aldehyde fuchsin positive B-cells containing many small blood vessels (Fig. 6b). These were easily observed by specific staining of erythrocytes with Orange-G. Generally the clusters of B-cells lacked other types of endocrine cells. This is in contrast with a normal islet of Langerhans (Fig. 6a) in which clusters of B-cells are surrounded by a clear border of A and $D$ cells.

This phenomenon was confirmed by electronmicroscopic examination. Figure 7 a shows a section of the islet of Langerhans of a normal rat. Three types of endocrine cells are grouped around a capillary. A magnification of the outlined area of this figure is shown in Figure $8 \mathrm{a}$. In this figure signs of exocytosis can be seen.
B-cells of the transplanted group appear normal and are well granulated (Fig. 7 b). Figure 8 b shows a higher magnification of the contact of a B-cell with a capillary. Note the signs of exocytosis.

\section{Discussion}

The parasympathetic and probably also the sympathetic nervous systems are involved in the secretion of insulin [16]. In this study neonatal pancreatic tissue was transplanted in alloxan diabetic rats in order to investigate the role of the autonomic nervous supply to the islets of Langerhans. The transplantations were successful as judged by normalisation of body weight and urine production (Fig. 1). Histological examination revealed that the recovered islets were well vascularised and composed primarily of aldehyde fuchsin positive B-cells. This phenomenon has also been observed by others [21]. Electronmicroscopy shows well granulated B-cells very close to the blood vessels with many electrondense granules along the cell periphery. The presence of these granules along this border is associated with rapid 

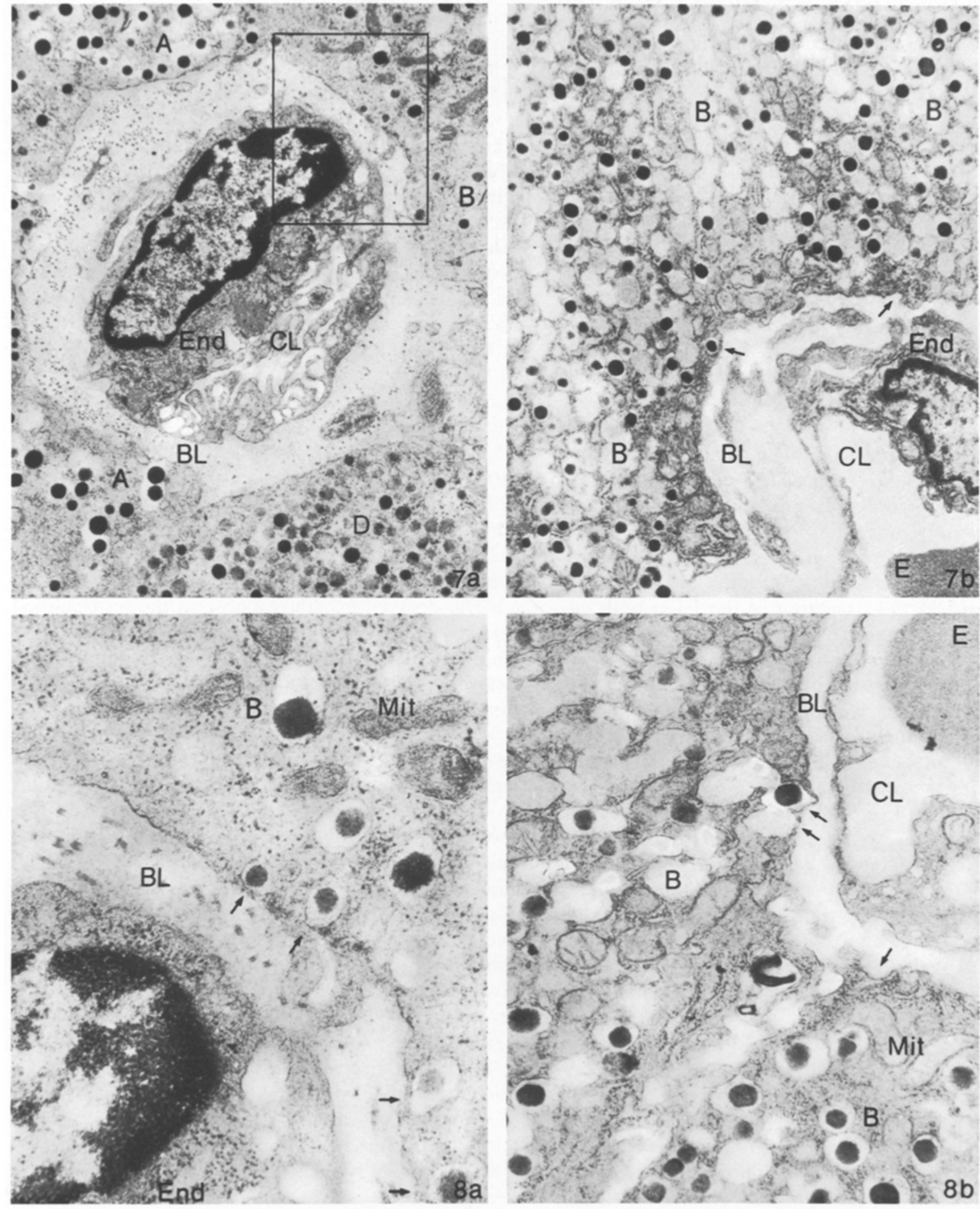

Fig. 7. a Thin section of a part of the islet of Langerhans of a normal rat. Three types of endocrine cells can be seen grouped around a capillary. A-cell (A), B-cell (B) and D-cell (D). Capillary lumen (CL) and Basal lamina (BL). Endothelial cell (End). $\times 14,500$. The outlined area is shown in detail in Figure 8 a. b Endocrine tissue of a pancreatic transplant. B-cells (B) are the major component. The cells are grouped around a capillary Endothelial cell (End), Erythrocyte (E). Arrows indicate signs of exocytosis, $\times 11,000$

Fig. 8. a Magnification of outlined area in Figure 8 a. B-cell (B) and endothelial cell (End) of an islet of a normal rat. Signs of exocytosis are indicated by arrows. Mitochondria (Mit), $\times 54,500 . \mathbf{b}$ B-cell (B) and endothelial (End) of a transplanted pancreas. Arrows indicate signs of exocytosis. Erythrocyte (E). Mitochondrium (Mit). Capillary lumen (CL). $\times 20,000$ 
insulin release [22]. Further, Figure 2 shows that IV infusion of glucose in conscious rats elicits a biphasic pattern of insulin release similar to that seen in the isolated perfused pancreas as well as other in vivo studies [3, 23, 24]. Although other humoral factors than glucose may play a role in shaping the secretory response [25-27], the rapid insulin response in the first minute is certainly elicited by the rapid blood glucose elevation. These studies, therefore, indicate that humoral factors can release insulin within one minute from readily available pools of stored hormone in the transplanted tissue.

The insulin secretory response to food intake is a true physiological response. In the sham operated normal control animals the ingestion of a meal caused plasma insulin to rise $1 \mathrm{~min}$ prior to the first noticeable elevation of blood glucose, confirming previous observations [1-3]. This blood glucose independent early insulin response (EIR) also occurs during ingestion of indigestible dummy meals [1]. The EIR is probably triggered by afferent nervous signals arising from the oropharyngeal cavity $[28,29]$. Available evidence suggests that efferent vagal projections are involved in the triggering of the EIR: both vagotomy and pharmacological blockade of muscarinic receptors by atropin abolish the EIR $[1,4,6]$. However, indirect stimulation by vagally mediated release of enteric hormones cannot be excluded [8].

In contrast to effects observed in control and regenerated rats the EIR is absent in transplanted rats, despite the possibility of a response within one minute (Fig. 2). Therefore the present data suggest that the pre-absorptive insulin release is triggered by a direct vagal influence.

During the first $10 \mathrm{~min}$ in the fed condition, blood glucose increased in the transplanted group to a value which was almost twice that of controls. By that time much more insulin was secreted in controls. This lack in initial insulin release in the transplants may also account for the exaggerated glucose increase in the first $10 \mathrm{~min}$. In the transplanted group the sharp plasma insulin rise and subsequent high level is probably due to the higher blood glucose levels when compared with controls, though the following alternative explanations are possible.

The nature of the blood drainage of the transplanted tissue is not known, but we assume that it possesses systemic rather than portal drainage. Under normal conditions insulin is drained into the portal vein and some of it is removed by the liver [30]. The difference in drainage may account for the higher insulin levels. Since the liver is an important target organ for insulin, the difference in insulin drainage may also account for the higher glucose levels. A possible higher mass of B-cells, through transplantation of eight neonatal pancreases, may also have contributed to the exaggerated insulin release. However, this release was adequate in that it did not result in hypoglycaemia.

It is remarkable, however, that after the peak at 20 min plasma insulin remained relatively high in the transplanted group but decreased sharply in controls. Since glucose levels did not differ very much between the two groups it is possible that in the controls inhibition of the B-cell caused the rapid fall in insulin, a possibility discussed previously [3]. If we assume that the transplanted pancreas is denervated, inhibition by the sympathetic nervous system may be a factor influencing the controls [16]. Alternatively, the lack of other endocrine tissue, including somatostatin producing D-cells in the neighbourhood of the B-cells (Fig. $6 \mathrm{~b}$ and $7 \mathrm{~b}$ ) as can be seen in normal islets (Fig. 6a and 7a) [21], may account for the lack of inhibition in the transplanted group [31]. It is possible that somatostatin fulfills this inhibitory role in controls by a direct influence from D-cell to B-cell [32] or via the blood circulation within the islet of Langerhans (Fig. $7 \mathrm{a}$ ).

The delayed insulin response in the transplanted rats resembles the insulin response of human prediabetics, in whom a lower first phase response with a delayed and sometimes higher second phase insulin response is seen [24, 33-35].

Not only the early phase insulin release seems to be of physiological importance in glucose homeostasis, but also the second phase release. Blood glucose levels of the regenerated group rose more than those of the control group, in particular from $10 \mathrm{~min}$ onwards. Despite these high blood glucose levels, the second phase of insulin release was relatively small, and in the fed condition the insulinogenic index was even lower than that of the controls in the fasted condition. It is possible that the higher blood glucose levels are caused by the lower insulin release in the second phase. Two explanations are possible for the decreased insulin response. The sensitivity for glucose stimulation may be lowered, but more likely is a decreased capacity of insulin release by a decrease of the B-cell population. Indeed by histological examination a decrease of about $30 \%$ of the number of stained B-cells was observed in the regenerated group.

The basal levels of insulin and glucose of control rats and recipients are lower in the fasted than in the fed state. Further fasting decreases the insulin secretory responses. The response of the B-cell to increased blood glucose levels expressed as the insulinogenic index was significantly lower in fasted control and recipient rats but there was no significant difference between controls and recipients. 
In vivo and in vitro studies on insulin secretion of the rats have shown that the insulin secretory responses to glucose stimulation are markedly reduced in the fasting state $[9-11,36]$. The mechanisms behind this phenomenon have been subjected to many studies [12-15]. Recent studies indicate that c-AMP, which plays a key role in glucose induced insulin secretion, is decreased by fasting $[12,13]$. It has been reported that acetylcholine, the muscarinic post-synaptic transmitter of the vagus nerve, enhances insulin release [16] and stimulates the adenylcyclase activity in the islets of Langerhans [26]. On the other hand, catecholamines released by the sympathetic nervous system inhibit insulin secretory responses by decreasing the c-AMP content in the islets [38]. Catecholamines possibly also influence insulin secretion by modulation of the blood flow through the islets $[37,39]$. However, it is unlikely that the decreased insulin response after fasting is attributed to re-innervation of the transplanted tissue with an autonomic nerve supply. Therefore, humoral factors are the probable causal factors here. In this respect, various intestinal hormones are involved in insulin secretion in mouse and rat pancreatic islets $[26,27]$. Gastric inhibitory polypeptide, cholecystokinin, and other intestinal peptides have been advocated as likely candidates for this role $[26,27]$ but relevant studies in vivo in the rat are relatively scarce.

After fasting in control, transplanted and regenerated rats blood glucose levels decreased below $100 \mathrm{mg} / 100 \mathrm{ml}$ which is known to be a threshold level for insulin secretion in vitro [23]. Recently it has been reported that even the lack of adequate levels of glucose decreases c-AMP synthesis $[12,13,15]$. A third factor involved, might be an increase of circulating catecholamines in the fasted condition [40]. At the moment we cannot distinguish to what extent these three factors contribute to a decreased insulin response after fasting.

In summary, this study shows that the triggering of the early insulin response after food intake is probably under nervous control. Furthermore it is suggested that mainly humoral factors are the causal factors for the decreased insulin response after fasting.

\footnotetext{
Acknowledgements. The authors wish to thank Dr. N. J. Spiteri, Ir. A. de Jong, Drs. G. H. J. Wolters, N. A. Gastkemper, H. R. A. Meiborg, M. Veenhuis, J. Zagers, R. Remie, J. N. Keyser and J. Poelstra-Hiddinga for their helpful comments and assistance.

This investigation was supported (in part) by the Foundation for Medical Research (FUNGO) which is subsidized by the Netherlands Organization for the Advancement of Pure Research (ZWO).
}

\section{References}

1. Strubbe JH, Steffens AB (1975) Rapid insulin release after ingestion of a meal in the unanesthetized rat. Am J Physiol 229: 1019-1022

2. De Jong A, Strubbe JH, Steffens AB (1977) Hypothalamic influence on insulin and glucagon release in the rat. Am J Physiol 233: E380-E388

3. Strubbe JH, Bouman PR (1978) Plasma insulin patterns in the unanesthetized rat during intracardial infusion and spontaneous ingestion of graded loads of glucose. Metabolism 27: 341-351

4. Fischer U, Hommel H, Freyse EJ, Fiedler H (1975) Der Mechanismus der Insulinsekretion nach oraler Glukoseverabfolgung. IV. Verhinderung der reflektorischen Frühphase des Plasmainsulin-Anstieges durch Atropin. Endokrinologie 65: 91-102

5. Fischer U, Hommel H, Ziegler M, Nowak W, Hahn von Dorsche $H$ (1976) The mechanism of insulin secretion after oral glucose administration. VIII. Pancreatic juice insulin excretion after glucose loading and meal ingestion in normal and vagotomized dogs. Endokrinologie 68: 327-337

6. Fischer U, Hommel H, Nowak W, Hahn von Dorsche H, Sill U, Lippert H (1976) Der Einfluß der Vagotomie auf die Glukosetoleranz sowie die Reaktionen von Plasmainsulin und exokriner Pankreasfunktion nach Glukosebelastung oder Nahrungsaufnahme bei Hunden. Acta Biol Med Germ 35: 1279-1291

7. Louis-Sylvestre $\mathbf{J}$ (1978) Feeding and metabolic patterns in rats with truncular vagotomy or with transplanted $B$ cells. Am J Physiol 235: E119-E125

8. Chisholm GJ, Young JD, Lazarus L (1969) The gastrointestinal stimulus to insulin release. I. secretin. J Clin Invest 48 : 1453-1459

9. Grey NJ, Goldring S, Kipnis DM (1970) The effect of fasting, diet, and actinomycin $\mathrm{D}$ on insulin secretion in the rat. J Clin Invest 49: 881-889

10. Feldman JM, Lebovitz HE (1973) Role of pancreatic monoamines in the impaired insulin secretion of the fasting state. Endocrinology 92: 1469-1473

11. Feldman JM, Lebovitz HE (1970) Effect of fasting on insulin secretion and action in mice. Endocrinology 86: 313-321

12. Wolters GHJ, Konijnendijk W, Bouman PR (1977) Effects of fasting on insulin secretion, islet glucose metabolism and the cyclic adenosine 3', 5'-monophosphate content of rat pancreatic islets in vitro. Diabetes 26: 530-537

13. Bouman PR, Wolters GHJ, Konijnendijk W (1979) Insulin secretion and cyclic Adenosine 3', 5'-monophosphate levels in pancreatic islets of fed and fasted rats. Diabetes 28: 132-140

14. Lavine RL, Voyles N, Perrino PV, Recant L (1975) The effect of fasting on tissue cyclic cAMP and plasma glucagon in the obese hyperglycemic mouse. Endocrinology 97: 615-620

15. Hedeskov CJ, Capito K (1974) The effect of starvation on insulin secretion and glucose metabolism in mouse pancreatic islets. Biochem J 140: 423-433

16. Woods SC, Porte D (1974) Neural control of the endocrine pancreas. Physiol Rev 54: 596-618

17. Efendić S, Cerasi E, Luft R (1975) Effect of phentolamine and preperfusion with glucose on insulin release from the isolated perfused pancreas from fasted and fed rats. Diabetologia 11: $407-410$

18. Brown J, Clark WR, Molnar IG, Mullen YS (1976) Fetal pancreas transplantation for reversal of streptozotocin-induced diabetes in rats. Diabetes 25: 56-64

19. Steffens AB (1969) A method for frequent sampling of blood and continuous infusion of fluids in the rat without disturbing the animal. Physiol Behav 4: 833-836 
20. Strubbe JH (1974) A small swivel joint for infusion of freely moving animals. Physiol Behav 12: 317-319

21. Hegre OD, Leonard RJ, Erlandson SL, McEvoy RC, Parsons JA, Elde RP, Lazarow A (1976) Transplantation of islet tissue in the rat. Acta Endocrinol [Suppl 205] (Kbh) 83: 257-281

22. Van Obberghen E, Somers G, Devis G, Ravazzola M, Malaisse-Lagae F, Orci L, Malaisse WJ (1975) Dynamics of insulin release and microtubular-microfilamentous system. Diabetes 24: 892-901

23. Grodsky GM (1972) A threshold distribution hypothesis for packet storage of insulin and its mathematical modeling. J Clin Invest 51: 2047-2059

24. Cerasi E (1975) Mechanisms of glucose stimulated insulin secretion in health and in diabetes: Some re-evaluations and proposals. Diabetologia 11: 1-13

25. McIntyre N, Holdsworth CD, Turner DS (1965) Intestinal factors in the control of insulin secretion. $\mathrm{J}$ Clin Endocrinol Metab 25: 1317-1324

26. Kuo WK, Hodgins DS, Kuo JF (1973) Adenylate cyclase in islets of Langerhans. Isolation of islets and regulation of adenylate cyclase activity by various hormones and agents. $J$ Biol Chem 248: 2705-2709

27. Pederson RA, Brown JC (1979) Effect of cholecystokinin secretin and gastric inhibitory polypeptide on insulin release from the isolated perfused rat pancreas. Can J Physiol Pharmacol 57: 1233-1237

28. Hommel H, Fischer U, Retzlaff K, Knöffler H (1972) The mechanism of insulin secretion after oral glucose administration. Diabetologia 8: 111-116

29. Steffens AB (1976) Influence of the oral cavity on insulin release in the rat. Am J Physiol 230: 1411-1415

30. Navalesi R, Pilo A, Ferrannini E (1976) Insulin kinetics after portal and peripheral injection of ${ }^{125}$ I-insulin II: Experiments in the intact dog. Am J Physiol 230: 1630-1636

31. Curry DL, Benett LL (1976) Does somatostatin inhibition of insulin secretion involve two mechanisms of action? Proc Natl Acad Sci USA 73: 248-251
32. Orci L (1976) The microanatomy of the islets of Langerhans. Metabolism 25 [Suppl 1]: 1303-1313

33. Fujita Y, Herron Jr AL, Seltzer HS (1975) Confirmation of impaired early insulin response to glycemic stimulus in nonobese mild diabetics. Diabetes 24: 17-27

34. Seltzer HS, Allen EA, Herron Jr AL, Brennan MT (1967) Insulin secretion in response to glycemic stimulus: Relation of delayed initial release to carbohydrate intolerance in mild diabetes mellitus. J Clin Invest 46: 323-335

35. Kipnis DM (1972) Nutrient regulation of insulin secretion in human subjects. Diabetes 21: 606-616

36. Fink G, Gutman RA, Cresto JC, Selawry H, Lavine R, Recant L (1974) Glucose-induced insulin release patterns: Effects of starvation. Diabetologia 10: 421-425

37. Richardson DR, Coates F (1975) Effects of norepinephrine infusion (iv) on microvascular pressures and capillary blood flow in the mesentery. Microvasc Res 9: 166-181

38. Turtle JR, Kipnis DM (1967) An adrenergic receptor mechanism for the control of 3'5'-adenosine monophosphate synthesis in tissues. Biochem Biophys Res Commun 28: 797-802

39. Bunnag SC, Bunnag S, Warner NE (1963) Microcirculation in the islets of Langerhans of the mouse. Anat Rec 146: 117-124

40. Christensen NJ (1974) Plasma norepinephrine and epinephrine in untreated diabetics, during fasting and after insulin administration. Diabetes 23: 1-8

Received: May 30, 1980,

and in revised form: October 20, 1980

Dr. J. H. Strubbe

Department of Zoology

State University of Groningen

P. O. Box 14

9750 AA Haren

The Netherlands 